\title{
Fatal Blastoschizomyces capitatus sepsis in a diabetic patient with sinusitis
}

\author{
Poonam Sharma, Aruna Aggarwal, Maninder Kaur \\ Department of Microbiology, Sri Guru Ram Das Institute of Medical Sciences and Research (SGRDIMSAR), Amritsar, Punjab, \\ India
}

\begin{abstract}
Blastoschizomyces capitatus is an emerging fungal pathogen. We describe a case of fungal sinusitis and invasive fungal septicemia due to $B$. capitatus in a 65 -year-old male patient who was a known cardiac and diabetic patient. The patient was treated with antibiotics but succumbed due to delay in treatment with amphotericin-B. J Microbiol Infect Dis 2012; 2(4): 165-167
\end{abstract}

Key words: Blastoschizomyces capitatus, fungal sinusitis, diabetes

\section{Sinüziti olan diyabetik hastada fatal seyreden bir Blastoschizomyces capitatus sepsisi} ÖZET

Blastoschizomyces capitatus önemli bir fungal patojendir. Burada daha önce kalp hastalığı ve diyabeti olduğu bilinen 65 yaşındaki bir erkek hastada gelişen fungal sinüzit ve invazif fungal septisemi sunulmaktadır. Hasta antibiyotik ve amfoterisin-B ile tedavi edildi, fakat antifungal tedavideki gecikme nedeniyle kaybedildi.

Anahtar kelimeler: Blastoschizomyces capitatus, fungal sinüzit, diyabet

\section{INTRODUCTION}

Blastoschizomyces capitatus was previously known as Trichosporon capitatum, Geotrichum capitatum and Blastoschizomyces pseudotrichosporom, and was considered a new genus in 1985 after the suggestion by Salkin and colleagues. $^{1}$

It was considered as a non-pathogenic fungus until 25 years ago and is now recognized as emerging fungal pathogen in immunocompromised patients. ${ }^{2}$ It has been isolated in sputum, faeces, oral mucosa, skin and liquids for intravenous infusion as well as in environmental samples. $^{3-6}$

B. capitatus can cause dermatomycosis, onychomycosis ${ }^{7-9}$ and some deep localized lesions, but its greatest danger lies in its capacity to cause disseminated and invasive mycoses, particularly in severely immunodepressed patients. Neutropenia is the most important predisposing factor, followed by the use of corticosteroids and other immunodepressors. ${ }^{7-9}$ We report here a case of fungal sinusitis which eventually lead to invasive fungal septicemia.

\section{CASE REPORT}

A 65-year-old male patient presented with fever and swelling over right half of the face which was preceded by pain in pre-auricular region and accompanied with difficulty in swallowing solids. The diffuse swelling was seen extending over right cheek, upper part of neck and right lower lid. Skin over the area was inflamed and right half of oral cavity was also oedematous. The patient was a known diabetic since 8 years and also a cardiac patient with history of irregular medication. On investigating, random blood sugar was $382 \mathrm{mg} / \mathrm{dl}$ and glycosylated hemoglobin was $9.9 \%$ (markedly raised). Total leukocyte count was raised $(19,600 /$ cumm) with $86 \%$ neutrophils. Kidney function tests \& serum electrolytes were within normal range. The patient was also found to be negative for Hepatitis $B$ surface antigen and

Correspondence: Poonam Sharma, Assistant Professor, Department of Microbiology, Sri Guru Ram Das Institute of Medical Sciences And Research (SGRDIMSAR), Amritsar, Punjab, India Fax: 0183-2587621 Email: poonam136@rediffmail.com Received: 11 August, 2012 Accepted: 20 September, 2012

Copyright (C) Journal of Microbiology and Infectious Diseases 2012, All rights reserved 
for antibodies to HIV and hepatitis C virus. CT scan report showed cerebritis with sinusitis.

The patient was treated with co-amoxiclav, gentamycin and metronidazole. He was put on insulin therapy. In spite of the treatment the patient became unconscious next day. He was intubated and endoscopic nasal biopsy was taken which was sent for bacteriological culture, fungal culture, $\mathrm{KOH}$ and histopathological examination. Patient's blood sample was also sent for culture. $\mathrm{KOH}$ preparation (Ten percent) of the biopsy showed the presence of thin, septate, hyaline fungal hyphae with narrow angle branching and pleomorphic yeast-like cells. For fungal culture Sabouraud's dextrose agar (SDA) with and without cycloheximide was inoculated in duplicate, one set was incubated at $25^{\circ} \mathrm{C}$, while the second set was incubated at $37^{\circ} \mathrm{C}$. While the bacteriological culture was sterile, pure growth of several white to cream colored colonies was seen on SDA with and without cycloheximide after $48 \mathrm{hrs}$ of incubation at $37^{\circ} \mathrm{C}$ (Figure 1). Periodic acid schiff (PAS) stained sections of the biopsy revealed the presence of small fragments of fungal hyphae with a few yeast cells. Pure growth of white to cream coloured colonies was obtained on blood culture after $72 \mathrm{hrs}$ of incubation at $37^{\circ} \mathrm{C}$.

Microscopic characterization of the fungal isolate was carried out by preparing a lactophenol cotton blue (LPCB) mount from the growth. LPCB mount (Figure 2) showed true hyphae, pseudohyphae and annelloconidia resembling arthroconidia.

Further on subculture, growth was also obtained at $45^{\circ} \mathrm{C}$. Glucose and galactose were assimilated. The isolated fungus was unable to utilize urea. The characteristics of the creamy-white colonies obtained on the blood culture were same as that of the one isolated on SDA plate. Based on the above mentioned characteristics, the fungal isolate was identified as $B$. capitatus.

Liposomal form of amphotericin-B $5 \mathrm{mg} /$ $\mathrm{kg} /$ day intravenously was started based on the $\mathrm{KOH}$ preparation findings. The patient seemed to improve and swelling over the face and eye reduced. His vitals were maintained and he became semiconscious. After $24 \mathrm{hrs}$, patient developed hypotension and congestive cardiac failure which did not respond to inotropic support and died due to cardiac arrest.

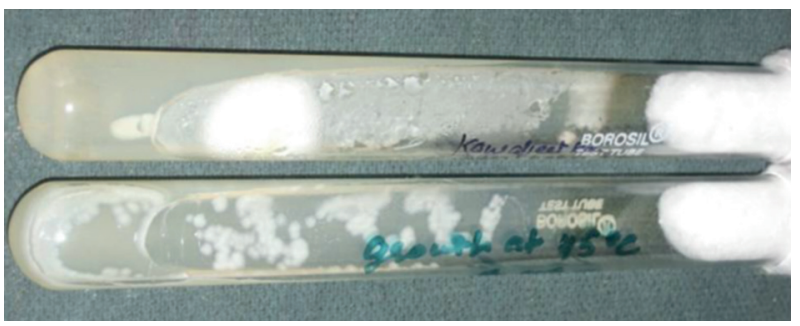

Figure 1. Sabouraud's Dextrose Agar with cycloheximide and Sabouraud's Dextrose Agar incubated at $45^{\circ} \mathrm{C}$ showing cream coloured yeast like colonies of Blastoschizomyces capitatus

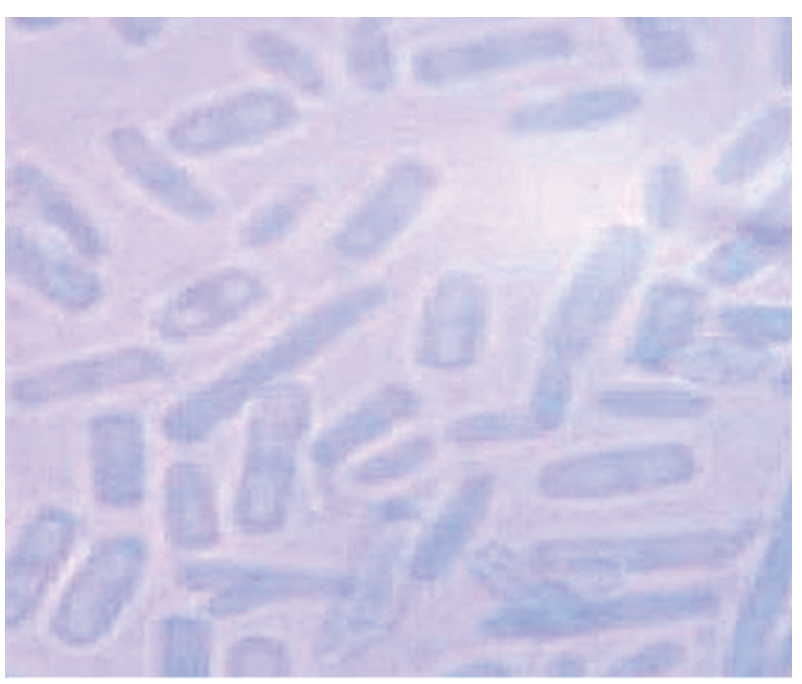

Figure 2. Lactophenol Cotton blue mount showing annelloconidia and pseudohyphae

\section{DISCUSSION}

Opportunistic fungal infections have emerged as important causes of morbidity and mortality in patients with severe underlying illnesses and compromised host defenses. ${ }^{10}$ Earlier Aspergillus spp. and Candida spp. collectively accounted for the majority of invasive and life-threatening fungal infections, ${ }^{11-13}$ but now epidemiological trends indicate a shift towards infections by Aspergillus spp., non-albicans Candida spp., as well as previously uncommon opportunistic fungi like Trichosporon beigelli, Fusarium and B. capitatus etc. ${ }^{14-16}$

Several components of the case point to $B$. capitatus as being either the sole infectious agent causing disease or at least a significant contributor. Of significant importance is the isolation of the organism from the nasal biopsy and the blood culture. Although $B$. capitatus is a colonizer of the 
normal respiratory tract, isolation of a pure culture of the organism suggests a role in the patient's clinical presentation.

Conceptually, these emerging fungal infections develop in a dynamic interplay of altered hosts, permissive environmental conditions, and selective antifungal pressures. Because of the lack of specific clinical, radiographic and histological features and the absence of diagnostic surrogate markers in blood, the diagnosis depends on the identification of the organism by means of culture based methods. The therapy of most emerging pathogens is not standardized but relies on the use of high dose amphotericin-B, appropriate surgical measures, and reversal of the underlying impaired host defense. The outcome of invasive disease caused by $B$. capitatus depends mainly on patient immunity. Since patient in this study was a known diabetic on irregular medication this could have been an important risk factor for development of fungal sinusitis due to $B$. capitatus.As the patient was not put on amphotericin-B right at the beginning, he had a rapid deterioration and was lost. The nature of this fungal infection is rapid progression with poor prognosis.

Finally, prompt diagnosis and aggressive treatment can only be achieved with increased awareness and better cooperation between clinicians, microbiologists and pathologists.

Ethical approval: Not required. Written informed consent was obtained from the patient's relative for publication of this case report and the accompanying images.

\section{REFERENCES}

1. Salkin I, Gordon M, Samsonoff W, Rieder C. Blastoschizomyces capitatus, a new combination. Mycotaxon 1985; 22:375380.
2. Wills T.S, Degrese A. et al. Blastoschizomyces capitatus pneumonia in an immunocompetant male. J South Med Assoc 2004; 97:702-704.

3. Gemeinhardt $\mathrm{H}$. On the problem of pathogenicity of the yeast fungus Trichosporon capitatum in the respiratory tract of man. A contribution to the diagnosis of pulmonary mycoses. Z Tuberk Erkr Thoraxorg 1965; 124:190-197.

4. Martino P, Venditti M, Micozzi A et al Blastoschizomyces capitatus: an emerging cause of invasive fungal disease in leukemia patients. Rev Infect Dis 1990; 12:570-582.

5. Randhawa HS, Mussa AY, Khan ZU. Decaying wood in tree trunk hollows as a natural substrate for Cryptococcus neoformans and other yeast-like fungi of clinical interest. Mycopathologia 2001; 151:63-69.

6. Mathews MS, Sen S. Blastoschizomyces capitatus infection after contamination of fluids for intravenous application. Mycoses 1998; 41:427-428.

7. D'Antonio D, Romano F, lacone A et al. Onychomycosis caused by Blastoschizomyces capitatus. J Clin Microbiol 1999; 37:2927-2930.

8. Grunder K. Trichosporon capitatum as pathogen of dermatomycoses. Hautarzt 1976; 27:422-425.

9. Restrepo A, De Uribe L. Isolation of fungi belonging to the genera Geotrichum and Trichosporum from human dermal lesions. Mycopathologia 1976; 59:3-9.

10. Duong TA. Infection due to Penicillium marnefei, an emerging pathogen: review of 155 reported cases. Clin Infect Dis 1996;23:125-130.

11. Groll AH, Shah PM, Mentzel C, Schneider M, Just-Nuebling $\mathrm{G}$, Huebner K. Trends in the postmortem epidemiology of invasive fungal infections at a university hospital. J Infection 1996; 33:23-32.

12. Nguyen MH, Peacock JE Jr, Moms AJ et al. The changing face of candidemia: emergence of non-Candida albicans species and antifungal resistance. Am J Med 1996;100:617623.

13. Wald A, Leisenring W, Van Bunk JA, Bowden RA. Epidemiology of Aspergillus infections in a large cohort of patients undergoing bone marrow transplantation. J Infectious Dis 1997;175:1459-1466.

14. Vamvarian SE, Anaissie EJ, Bodey GP. Emerging fungal pathogens in immunocompromised patients: classification, diagnosis, and management. Clin Infect Dis 1993; 17 (Suppl. 2): S487-491.

15. Cunliffe NA, Denning DW. Uncommon invasive mycoses in AIDS. 1995;9:411-420.

16. Perfect JR, Schell WA. The new fungal opportunists are coming. Clin Infect Dis 1996; 22 (Suppl. 2): S112-118. 